\title{
Molecular genetics of autism spectrum disorders
}

Received: 16 June 2003/ Accepted: 22 July 2003/Published online: 11 September 2003

(C) The Japan Society of Human Genetics and Springer-Verlag 2003

\begin{abstract}
Autistic disorder belongs to a broad spectrum of pervasive developmental disorders. Autism is a clinically and genetically heterogeneous condition. It is characterized by impairment in a broad range of social interactions, communication, and repetitive patterns of behavior and interest. Although the exact etiology of the condition is not known, family and twin studies strongly support genetic factors in autism. Genome-wide scans suggest several susceptibility loci that may contain one or more predisposing genes. However, no such genes have been identified so far that predispose patients to autism. The condition is over $90 \%$ heritable, but the mode of inheritance is not clear. Moreover, it does not seem to be a single gene disorder. There is no cure for autism. Individualized structured education, family support services, and antipsychotic drugs are recommended. These may alleviate some behavioral problems. The identification of autism genes, an understanding of the neurobiology of the condition, and additional clinical studies may help to develop pharmacological interventions in the future.
\end{abstract}

Keywords Linkage ' Gene Cytogenetic Chromosome

\section{Introduction}

Autism is a neurodevelopmental disorder with variable clinical presentations and usually occurs before 3 years of age (Bailey et al. 1996). It is a poorly understood condition and belongs to a group of several closely related pervasive developmental disorders (PDD) such as Asperger syndrome and childhood disintegrative disor-

B. S. Shastry $(\bowtie)$

Department of Biological Sciences,

Oakland University,

Rochester, MI 48309, USA

E-mail: shastry@oakland.edu

Tel.: + 1-248-3703577

Fax: + 1-248-3704225 ders. The more popular term for the condition is autism spectrum of pervasive developmental disorders. It is a life-long disorder and is clinically characterized by impairment in social interactions, communication, imagination, and language. Additionally, repetitive patterns of behavior such as movement of hands and fingers have been documented (Prater and Zylstra 2002; American Psychiatric Association 2000; Lewis and Thompson 1992; Bishop et al. 1995; Tomblin and Buckwalter 1998; Wing and Gould 1979; Wing 1997). The disorder can also be associated with a wide range of conditions. Autistic-spectrum disorders are a tremendous burden on the lives of affected individuals, their families, and society.

\section{Pathology, epidemiology, and etiology}

Magnetic resonance imaging studies and postmortem examination of the brain revealed changes in the limbic system and a larger volume of white matter (Casanova et al. 2002; Piven et al. 1996). Microscopic neuroanatomical abnormalities such as reduced neuronal cell size and increased cell packing found in the hippocampal and amygdala region support the notion that normal brain development is impaired (Critchley et al. 2000; Bauman 1996; Kemper and Bauman 1998). This is consistent with experiments involving primates in which early hippocampal damage produced stereotypies and loss of social affiliation, suggesting again that the hippocampal region may be involved in normal social interactions (Beauregard et al. 1995).

Additionally, neuropsychological findings suggest structural and functional abnormalities in the temporal lobe (Dawson 1996; Lainhart 1997; Fombonne 1999), which has been supported by experiments in newborn monkeys (Bachevalier 1994). In these experiments, a major behavioral disturbance was found in monkeys that have lesions in the medial temporal lobe structures. This has been further supported by positron emission tomography that showed a highly significant hypoper- 
fusion in both temporal lobes in school-aged children with autism (Zilbovicius et al. 2000). In addition, hypometabolism of both temporal lobes was found to be associated with autism (Chugani et al. 1996). However, it is not clear whether the abnormality in one part of the brain is responsible for autism or other areas are also involved. There are several pathological and pathophysiological questions that need to be answered before one can understand the full spectrum of the disorder. Developmental disturbance of the neuronal network in the medial temporal lobe on the other hand, appears to be a contributing factor to the development of autism.

A recent epidemiological survey involving preschool children suggests its prevalence of 58-67 per 10,000 when all forms of autism spectrum disorders are combined (Chakrabarti and Fombonne 2001; Baird et al. 2000). But this needs to be confirmed by more studies. When taking into consideration this value, it appears that it is a more common childhood disorder than previously thought. It is also three to four times more common in males than in females, and there is an increased incidence of the disorder among relatives of individuals with the disorder. According to a recent twin study in the general population, the lower prevalence of the disorder in girls could be due to early environmental influences (Constantino and Todd 2003). The biochemical basis of the disorder is not known. It is believed that an early insult to the central nervous system by a wide variety of heritable and nonheritable factors may cause the disease (Newschaffer et al. 2002). Available evidence strongly suggests that genetic factors may play a major etiological role in the pathogenesis of autism.

\section{Chromosomal loci suggestive of linkage}

Autism is a life-long neurodevelopmental condition. Although the molecular basis of the disorder is not known, family and twin studies strongly support genetic factors in autism (Folstein and Rutter 1977; Steffenburg et al. 1989; Bolton et al. 1994; Bailey et al. 1995; Cook 1998a; Spiker et al. 1994). Monozygotic and dizygotic twin studies suggest a concordance rate of $90 \%$ and $30 \%$ respectively (Folstein and Rutter 1977; Ritvo et al. 1985; Trottier et al. 1999) and there is a 75 -fold greater risk among siblings. However, the twinning process itself is not found to be a risk factor for autism (Hallmayer et al. 2002), which is in contrast to what was previously suggested by others (Greenberg et al. 2001; Betancur et al. 2002).

Although it has a high heritability rate, the mode of transmission of autism is not clear, and the genetics of the disorder appears to be complex, involving multiple loci and interaction of multiple genes (Risch et al. 1999). In accordance with this, several genome-wide scans and linkage studies have identified multiple chromosomal regions (Risch et al. 1999; Folstein and Rosen-Sheidley 2001; Auranen et al. 2000; 2002; Philippe et al. 1999; Shao et al. 2002a; Liu et al. 2001; Barrett et al. 1999) that may contain one or more susceptible genes. However, no such genes have been identified so far. Although in some cases results are not replicated by other studies (Salmon et al. 1999), these studies have provided mostly suggestive evidence for linkage and must be interpreted with caution. The discrepancies among studies could be due to genetic heterogeneity or clinical presentation of the disorder, or differences in geographic and sample size used in the experiments. For instance, the frequency of variant alleles may differ among racial or ethnic groups, and some mutations may occur uniquely at a high frequency within a single racial group (e.g., Ashkenazi, Amish, and French Canadians). This is particularly important in complex genetic disorders such as neuropsychiatric conditions, diabetes, and asthma, in which multiple interacting genes and environmental factors contribute to the phenotype. In such cases, more studies using larger sample size may be needed to resolve the differences.

Among the loci identified, the most promising regions have been found on chromosome 7q (IMGSA 1998; 2001a; Fisher et al. 1998; Ashley-Koch et al. 1999) and 2q (IMGSA 2001b; Buxbaum et al. 2001; Shao et al. $2002 \mathrm{~b}$ ) in which several genome scans identified overlapping linkage. This multiloci genetic etiology is also consistent with phenotypic variability of the disorder within families. It should be mentioned here that these genetic studies have been conducted with infantile autism in which some patients are associated with other phenotypes. In order to apply genetic methods, it will be helpful to identify families having a single disease phenotype.

\section{Cytogenetic abnormality}

Numerous studies have revealed that several cases of autism have been associated with chromosomal abnormalities such as deletion, duplication, balanced, unblanced and complex translocations ( $\mathrm{Yu}$ et al. 2002; Smith et al. 2000; Thomas et al. 1999; Vostanis et al. 1994; Michaelis et al. 1997; Nurmi et al. 2001; Burd et al. 1998; Ghazziuddin and Burnmeister 1999; Smith et al. 2001; Gillberg et al. 1991; Yan et al. 2000; Vincent et al. 2001; Tentler et al. 2001; Wolpert et al. 2001). Although in some cases deletions ranged from 5 to $260 \mathrm{~kb}$ and patients exhibited a varying degree of intellectual impairments (Bolton et al. 2001a), there is no clustering of breakpoints involved and deletions are scattered throughout the genome. It is possible that the above chromosomal abnormalities would cause autism in combination with other unidentified loci. Alternatively, chromosomal rearrangements and deletions could be due to autism susceptibility loci located in some other regions in the genome that may increase errors in meiosis. This notion is supported by the finding that in some autism patients, meiosis is altered relative to control families (Ashley-Koch et al. 1999; Bass et al. 1999). Since there is no such increased recombination rate or gene 
defect so far reported in any other inherited diseases, further studies are needed to confirm the above hypothesis.

\section{Candidate gene analysis}

Since several genome-wide scans have identified many susceptibility loci, it is logical to extend these observations to identify candidate genes that predispose patients to autism spectrum disorders. However, when specific candidate genes such as HOXA1, HOXB1 (Ingram et al. 2000), EN-2 - a human homeogene (Petit et al. 1995), FOXP2 - a forkhead transcription factor gene (Newbury et al. 2002; Wassink et al. 2002), serotonin transporter SLC6A4 (Cook et al. 1997a; Yirmiya et al. 2001; Kim et al. 2002a), reelin - a large extracellular matrix protein gene involved in neuronal migration (Persico et al. 2001), vasoactive intestinal peptide receptor type 2 (Asano et al. 2001), RAY1 (Vincent et al. 2000), GABA receptor (Cook et al. 1998b), DLX6 (Nabi et al. 2003), DOPA decarboxylase (Lauritsen et al. 2002), tyrosine hydroxylase, dopamine receptors D2 and D5, proenkephalin, prodynorphin, monoamine oxidases $\mathrm{A}$ and $\mathrm{B}$, brain-derived neurotrophic factors (Philippe et al. 2002), sodium channels SCN1A, SCN2A, SCN3A (Weiss et al. 2003), methyl-CpG binding protein 2 (Lobo-Menendez et al. 2003), gamma - aminobutyric acid type A receptor $\beta$-3 subunit (Buxbaum et al. 2002), glutamate receptor 6 (Jamain et al. 2002), arginine vasopressin receptor 1A (Kim et al. 2002b), members of carboxypeptidase gene family-PEG1/MEST, COPG2, CPA1 and CPA5 (Bonora et al. 2002), and WNT2 (Wassink et al. 2001) have been analyzed, conflicting results are obtained and no gene has been conclusively identified as a candidate gene. Since some of the above candidate gene analyses are not replicated by other studies (Krebs et al 2002), the results should be interpreted with caution. Interestingly however, mice lacking the WNT2 gene that is implicated in brain development exhibited less social interaction, which is one of the hallmarks of human autism.

Recently, mutations in the neuroligins NLGN3 and NLGN4 (X-linked genes) have been found in siblings with autism spectrum disorders (Jamain et al. 2003), but this needs to be replicated by other studies before any conclusion can be made. If it holds, then autism could be due to defects in synaptogenesis.

\section{Environmental factors}

Although inheritance contributes substantially to autism, that does not mean that there are no other environmental risk factors (Rodier and Hyman 1998). Autism spectrum disorders could be due to heritable and nonheritable risk factors (Newschaffer et al. 2002). For instance, thalidomide and anticonvulsants taken during pregnancy seem to elevate the risk of the disorder (Zwaigenbaum et al. 2002; DeLong 1999). Similarly, intrauterine rubella (Chess 1997), cytomegalovirus (Iversson et al. 1990; Stubbs et al. 1984) infection, and premature birth with retinopathy of prematurity (Chase 1972) are implicated as risk factors. Among other factors, there was a considerable discussion about the occurrence of autism by immunization with the measles, mumps, and rubella vaccines. However, further careful examination of the data found no association with autism (Dales et al. 2001; Taylor et al. 2002). Therefore, they are no longer considered to be environmental risk factors.

\section{Association with other disorders}

Autism is occasionally associated with other disorders. These include tuberous sclerosis (Smalley et al. 1992; Bolton and Griffiths 1997), infantile macrocephaly (Bolton et al. 2001b), Angelman (Steffenburg et al. 1996), de Lang (Berney et al. 1999) syndrome, untreated phenylketonuria (Lowe 1980), Prader-Willi syndrome (Gillberg et al. 1991; Cook et al 1997b; Baker et al. 1994), mental handicap and epilepsy (Monaco and Bailey 2001), and chromosomal abnormalities (Gillberg 1998). The association of tuberous sclerosis and autism suggests that an early developmental abnormality in a brain region may lead to autism and atypical autism. This is further supported by experiments in newborn monkeys and very young children (Bachevalier 1994; Zilbovicius et al. 1995).

\section{Concluding remarks}

Autism is a childhood, complex, and heterogeneous lifelong condition. Impairment in social skills, language, and behavior are hallmarks of autism. Genetic and neurobiological abnormalities appear to be the etiological factors for autism. The biological basis of the disorder is unknown, and most of the studies to date have addressed genetic components of the disease. Genome-wide scans suggest multiple susceptibility loci, but no single gene has been identified as a predisposing factor. It does not seem to be a single gene disorder, and a complex etiology involving multiple loci has been proposed. It is possible that autism may be a series of syndromes or a syndrome caused by many different genes.

In order to explain the role of multigenes (15-20 genes) in which each gene plays a minor role in the etiology of the condition, a risk-factor model of epistatic interaction has been recently proposed (Jones and Szatmari 2002). This model predicts that addition of factors to the preexisting genetic insult increases the total risk. This accumulated effect need not be an additive type.

One major problem in identifying the autism gene is the clinical heterogeneity of the condition. For instance, it is not clear whether all hallmarks of autism (social and behavioral deficits) are due to a single gene defect or if it 
is a mixture of several disorders and several gene defects. Additionally, in some patients it could be a full and severe syndrome but in others it could be a milder syndrome (Piven J 2001). Identification of clinically homogeneous families and a kind of quantitative measure of phenotypes may help to understand the disorder at the genetic level (Silverman et al. 2002; Lord et al. 2001).

There is no cure for autism. Individualized structured or specialized education and appropriate advice and support for families may help affected individuals develop potential skills to handle behavioral disturbance effectively (Rogers 1998). In addition, antipsychotic medications, especially trazodone and serotonin reuptake inhibitors may minimize some of the behavioral problems such as severe agitation and self-destructive behavior. In the future, identification of predisposing autism genes, understanding the neurobiology of the condition, and contribution of environmental factors may lead to better diagnosis and improved treatment (Rapin and Katzman 1998).

\section{References}

American Psychiatric Association (1994) Diagnostic and statistical manual of mental disorders, 4th edn. American Psychiatric Association, Washington DC. pp 65-78

Asano E, Kuivaniemi H, Hug M, Tromp G, Behen M, Rothermel R, Herron J, Chugani DC (2001) A study of novel polymorphism in an upstream region of vasoactive intestinal peptide receptor type 2 gene in autism. J Child Neurol 16:357-363

Ashley-Koch A, Wolpert CM, Menold MM, Zaeem L, Basu S, Donnelly SL, Ravan SA, Powell CM, Qumsiyeh MB, Aylsworth AS, Vance JM, Gilbert JR, Wright HH, Abramson RK, DeLong GR, Cuccaro ML, Pericak-Vance MA (1999) Genetic studies of autistic disorder and chromosome 7. Genomics 61:227-236

Auranen M, Nieminen T, Majuri S, Vanhala R, Peltonen L, Jarvela I (2000) Analysis of autism susceptibility gene loci on chromosomes 1p, 4p, 6q, 7q, 13q, 15q, 16p, 17q, 19q and 22q in Finnish multiplex families. Mol Psychiatry 5:320-322

Auranen M, Vanhala R, Varilo T, Ayers K, Kampas E, YlisaukkoOja T, Sinsheimer JS, Peltonen L, Jarvela I (2002) A genomewide screen for autism spectrum disorders: evidence for a major susceptibility loci on chromosome 3q25-27. Am J Hum Genet 71:777-790

Bachevalier J (1994) Medial temporal lobe structures and autism: a review of clinical and experimental findings. Neuropsychologia 32:627-648

Bailey, A, Le Couteur A, Gottesman I, Bolton P, Simonoff E, Yuzda E, Rutter M (1995) Autism as a strongly genetic disorder: evidence from a British twin study. Psychol Med 25:63-77

Bailey A, Phillips W, Rutter M (1996) Autism: towards an integration of clinical, genetic, neuropsychological and neurobiological perspectives. J Child Psychol Psychiatry 37:89-126

Baird G, Charman T, Baron-Cohen S, Cox A, Swettenhain J, Wheelwright S, Drew A (2000) A screening instrument for autism at 18 months of age: a year follow-up study. J Am Acad Child Adolesc Psychiatry 39:694-702

Baker P, Piven J, Schwartz S, Patil S (1994) Brief report: duplication of chromosome 15q11-q13 in two individuals with autistic disorder. J Autism Dev Disord 24:529-535

Barrett S, Beck JC, Bernier R, Bisson E, Braun TA, Casavant TL, Childress D, Folstein SE, Garcia M, Gardiner MB, Gilman S, Haines JL, Hopkins K, Landa R, Meyer NH, Mullane JA,
Nishimura DY, Palmer P, Piven J, Purdy J, Santangelo SL, Searby C, Sheffield V, Singleton J, Slager S, Struchen T, Svenson S, Vieland V, Wang K, Winklosky B (1999) An autosomal genomic screen for autism. Am J Med Genet 88:609-615

Bass MP, Menold MM, Wolpert CM, Donnelly SL, Ravan SA, Hauser ER, Maddox LO, Vance JM, Abramson RK, Wright HH, Gilbert JR, Cuccaro ML, DeLong GR, Pericak-Vance MA (1999) Genetic studies in autistic disorder and chromosome 15. Neurogenet 2:219-226

Bauman ML (1996) Brief report: Neuroanatomic observations of the brain in pervasive developmental disorders. J Autism Dev Disord 26:199-203

Beauregard M, Malkova L, Bachevalier J (1995) Stereotypies and loss of social affiliation after early hippocampectomy in primates. Neuroreport 6:2521-2526

Berney TP, Ireland M, Burn J (1999) Behavioral phenotype of Corrnelia de Lange syndrome. Arch Dis Child 81:333-336

Betancur C, Leboyer M, Gillberg C (2002) Increased rate of Twins among affected sibling pairs with autism. Am J Hum Genet 70:1381-1383

Bishop DVM, North T, Donlan C (1995) Genetic basis of specific language impairment: evidence from a twin study. Dev Med Child Neurol 37:56-71

Bolton P, Macdonald H, Pickles A, Rios P, Goode S, Crowson M, Bailey A, Rutter M (1994) A case-control family history study of autism. J Child Psychol Psychiatry 35:877-900

Bolton PF, Griffiths PD (1997) Association of tuberous sclerosis of temporal lobes with autism and atypical autism. Lancet 349:392-395

Bolton PF, Dennis NR, Browne CE, Thomas NS, Veltman MWM, Thompson RJ, Jacobs P (2001a) The phenotypic manifestations of interstitial duplications of proximal $15 \mathrm{q}$ with special reference to the autistic spectrum disorders. Am J Med Genet 105:675-685

Bolton PF, Roobol M, Allsopp L, Pickles A (2001b) Association between idiopathic infantile macrocephaly and autism spectrum disorders. Lancet 358:726-727

Bonora E, Bacchelli E, Levy ER, Blasi F, Marlow A, Monaco AP, Maestrini E (2002) Mutation screening and imprinting analysis of four candidate genes for autism in the $7 \mathrm{q} 32$ region. Mol Psychiatry 7:289-301

Burd L, Martsolf JT, Kerbeshian J, Jalal SM (1988) Partial 6p trisomy associated with infantile autism. Clin Genet 33:356-359

Buxbaum JD, Silverman JM, Smith CJ, Kilifarski M, Reichert J, Hollander E, Lawlor BA, Fitzgerald M, Greenberg DA, Davis KL (2001) Evidence for a susceptibility gene for autism on chromosome 2 and for genetic heterogeneity. Am J Hum Genet 68:1514-1520

Buxbaum JD, Silverman JM, Smith CJ, Greenberg DA, Kilifarski, Reichert J, Cook EH Jr., Fang Y, Song C-Y, Vitale R (2002) Association between a GABRB3 polymorphism and autism. Mol Psychiatry 7:311-316

Casanova MF, Buxhoeveden DP, Switala AE, Roy E (2002) Minicolumnar pathology in autism. Neurol 58:428-432

Chakrabarti S, Fombonne E (2001) Pervasive developmental disorders in pre-school children. JAMA 285:3093-3099

Chase JB (1972) Retrolental fibroplasia and autistic symptomatology. New York, NY. American foundation for the blind

Chess S (1997) Follow-up report on autism in congenital rubella. J Autism Child schzophr 7:69-81

Chugani HT, Da Silva E, Chugani DC (1996) Infantile Spasms: III Prognostic implications of bitemporal hypometabolism on positron emission tomography. Ann Neurol 39:643-649

Constantino JN, Todd RD (2003) Autistic traits in the general population: a twin study. Arch Gen Psychiatry 60:524-530

Cook EH (1998a) Genetics of autism. Ment Retard Dev Disabil Res Rev 4:113-120

Cook EH, Courchesne RY, Lord C, Cox NJ, Yan S, Lincoln A, Haas R, Courchesne E, Leventhal BL (1997a) Evidence of linkage between the serotonin transporter and autistic disorder. Mol Psychiatry 2:247-250 
Cook EH, Lindgren V, Leventhal BL, Courchesne RY, Lincoln A, Shulman C, Lord C, Courchesne E (1997b) Autism or atypical autism in maternally but not paternally derived proximal $15 \mathrm{q}$ duplication. Am J Hum Genet 60:928-934

Cook EH, Courchesne RY, Cox NJ, Lord C, Gonen D, Guter SJ, Lincoln A, Nix K, Haas R, Leventhal BL, Courchesne E (1998b) Linkage disequilibrium mapping of autistic disorder with 15q11-12 markers. Am J Hum Genet 62:1077-1083

Critchley HD, Daly EM, Bullmore ET, Williams SC, Van Amelesvoort T, Robertson DM, Rowe RA, Phillips M, McAlonan G, Howlin P, Murphy DGM (2000) The functional neuroanatomy of social behavior: changes in cerebral blood flow in people with autistic disorder process facial expression. Brain 123:2203-2212

Dales L, Hammer SJ, Smith NJ (2001) Time trends in autism and in MMR immunization coverage in California. JAMA 285:1183-1185

Dawson G (1996) Neuropsychology of autism: a report on the state of the science. J Autism Dev Disord 26:179-184

DeLong GR (1999) Autism: new data suggest a new hypothesis. Neurol 52:911-916

Fisher SE, Vargha-Khadem, Watkin KE, Monaco AP, Pembrey ME (1998) Localization of a gene implicated in a severe speech and language disorder. Nat Genet 18:168-170

Folstein SE, Rosen-Sheidley B (2001) Genetics of autism: complex etiology for a heterogeneous disorder. Nat Rev Genet 2: 943-955

Folstein S, Rutter M (1977) Infantile autism: a genetic study of 21 twin pairs. J Child Psychol Psychiatry 18:297-321

Fombonne E (1999) The epidemiology of autism: a review. Psychol Med 29:769-786

Ghazziuddin M, Burnmeister M (1999) Deletion of chromosome 2q37 and autism: a distinct subtype? J Autism Dev Disord 29:259-263

Gillberg C, Steffenburg S, Wahlstrom J, Gillberg IC, Sjostedt A, Martinsson T, Liedgren S, Eeg-Olofsson O (1991) Autism associated with marker chromosome. J Am Acad Child Adolesc Psychiatry 30:489-494

Gillberg C (1998) Chromosomal disorders and autism. J Autism Dev Disord 28:415-425

Greenberg DA, Hodge SE, Sowinski J, Nicoll D (2001) Excess of twins among affected sibling pairs with autism. Am J Hum Genet 69:1062-1067

Hallmayer J, Glasson EJ, Bower C, Petterson B, Croen L, Grether J, Risch N (2002) On the twin risk in autism. Am J Hum Genet 71:941-946

Ingram JL, Stodgell CJ, Hyman SL, Figlewicz DA, Weitkamp LR, Roider PM (2000) Discovery of allelic variants of HOXA1 and HOXB1: genetic susceptibility to autism spectrum disorders. Teratology 62:393-405

IMGSA (1998) A full genome screen for autism with evidence for linkage to a region on chromosome 7q. Hum Mol Genet 7:571-578

IMGSA (2001a) Further characterization of the autism susceptibility locus AUTS1 on chromosome 7q. Hum Mol Genet 10:973-982

IMGSA (2001b) A genome-wide screen for autism: strong evidence for linkage to 2q, 7q and 16p. Am J Hum Genet 69:570-581

Iversson SA, Bjerre I, Vegfors P, Ahlfors K (1990) Autism as one of several disabilities in two children with congenital cytomegalovirus infection. Neuropediatrics 21:102-103

Jamain S, Betancur C, Quach H, Philippe A, Fellous M, Giros B, Gilberg IC, Leboyer M, Bourgeron T (2002) Linkage and association of the glutamate receptor 6 gene with autism. Mol Psychiatry 7:302-310

Jamain S, Quach H, Betancur C, Rastam M, Colineaux C, Gillberg IC, Soderstrom H, Giros B, Leboyer M, Gillberg C, Bourgeron $\mathrm{T}$ (2003) Mutations of the X-linked genes encoding neuroligins NLGN3 and NLGN4 are associated with autism. Nat Genet $34: 27-29$

Jones MB, Szatmari P (2002) A risk-factor model of epistatic interaction, focusing on autism. Am J Med Genet 114:558-565
Kemper TL, Bauman M (1998) Neuropathology of infantile autism. J Neuropathol Neurol 57:645-652

Kim S-J, Cox N, Courchesne R, Lord C, Corsello C, Akshoomoff N, Guter S, Leventhal BL, Courchesne E, Cook EH Jr (2002a) Transmission disequilibrium mapping at the serotonin transporter gene (SLC6A4) region in autistic disorder. Mol Psychiatry $7: 278-288$

Kim S-J, Young LJ, Gonen D, Veenstra-Vanderweele J, Courchesne R, Courchesne E, Lord C, Leventhal BL, Cook EH Jr., Insel TR (2002b) Transmission disequilibrium testing of arginine vasopressin receptor 1A (AVPR1A) polymorphism in autism. Mol Psychiatry 7:503-507

Krebs MO, Betancur C, Leroy S, Bourdel MC, Gillberg C, Leboyer $\mathrm{N}$ (202) Absence of association between a polymorphic GGC repeat in the 5' untranslated region of the reelin gene and autism. Mol Psychiatry 7:801-804

Lainhart JE (1997) Developmental abnormalities in autism. Lancet 349:373-374

Lauritsen MB, Borglum AD, Betancur C, Philippe A, Kruse TA, Leboyer M, Ewald H (2002) Investigations of two variants in the DOPA decarboxylase gene in patients with autism. Am J Med Genet 114:466-470

Lewis BA, Thomson LA (1992) A study of developmental speech and language disorders in twins. J Speech Hear Res 35:1086-1094

Liu J, Nyholt DR, Magnussen P, Parano E, Pavone P, Geschwind D, Lord C, Iversen P, Hoh J, Ott J, Gilliam TC (2001) A genome wide screen for autism susceptibility loci. Am J Hum Genet 69:327-340

Lobo-Menendez F, Sossey-Alaoui K, Bell JM, Copeland-Yates SA, Plank SM, Sanford SO, Skinner C, Simensen RJ, Schroer RJ, Michaelis RC (2003) Absence of MeCp2 mutations in patients from the South Carolina autism project. Am J Med Genet 117B: 97-101

Lord C, Leventhal BL, Cook EH Jr (2001) Quanttifying the phenotype in autism spectrum disorders. Am J Med Genet 105:36-38

Lowe TL, Tanaka K, Seashore MR, Young JG, Cohen DJ (1980) Detection of phenylketonuria in autistic and psychotic children. JAMA 243:126-128

Michaelis RC, Skinner SA, Deason R, Skinner C, Moore CL, Phelan MC (1997) Interstitial deletion of 20p: new candidate region for Hirschsprung disease and autism ? Am J Med Genet 71:298-304

Monaco AP, Bailey AJ (2001) The search for susceptibility genes. Lancet 358: suppl S3

Nabi R, Zhong H, Serajee FJ, Huq AHMM (2003) No association between single nucleotide polymorphisms in DLX6 and piccolo genes at 7q21-q22 and autism. Am J Med Genet 119B: 98-101

Newbury DF, Bonora E, Lamb JA, Fisher SE, Lai CSL, Baird G, Jannoun L, Slonims V, Stott CM, Merricks MJ, Bolton PF, Bailey AJ, Monaco AP (2002) FOXP2 is not a major susceptibility gene for autism or specific language impairment. Am J Hum Genet 70:1318-1327

Newschaffer CJ, Fallin D, Lee NL (2002) Heritable and nonheritable risk factors for autism spectrum disorders. Epidem Rev 24:137-153

Nurmi EL, Bradford Y, Chen YH, Hall J, Arnone B, Gardiner MB, Hutcheson HB, Gilbert JR, Pericak-Vance MA, Copelandyates SA, Michaelis RC, Wassink TH, Santangelo SL, Sheffield VC, Piven J, Folstein SE, Haines JL, Sutcliffe JS (2001) Linkage disequilibrium at the Angelman syndrome gene UBE 3A in autism families. Genomics 77:105-113

Persico AM, Dagruma L, Maiorano N, Totaro A, Militerni R, Bravaccio C, Wassink TH, Schneider C, Melmed R, Trillo S, Montecchi F, Palermo M, Pascucci T, Puglisiallegra S, Reichelt KL, Conciatori M, Marino R, Quattrocchi CC, Baldi A, Zelante L, Gasparini P, Keller F (2001) Reelin gene alleles and haplotypes as a factor predisposing to autistic disorder. Mol Psychiatry 6:150-159

Petit E, Herault J, Martineau J, Perrot A, Barthelemy C, Hameury L, Sauvage D, Lelord G, Muh JP (1995) Association study with two markers of a human homeogene in infantile autism. J Med Genet 32:269-274 
Philippe A, Martinez M, Guilloud-Bataille M, Gillberg C, Rastam M, Sponheim E, Coleman M, Zappella M, Aschauer H, Van Malldergerme L, Penet C, Feingold J, Brice A, Leboyer M (1999) Genome-wide scan for autism susceptibility. Hum Mol Genet 8:805-812

Philippe A, Guilloud-Bataille M, Martinez M, Gillberg C, Rastam M, Sponheim E, Coleman M, Zappella M, Aschauer H, Penet C, Feingold J, Brice A, Leboyer M (2002) Analysis of ten candidate genes in autism by association and linkage. Am $\mathbf{J}$ Med Genet 114:125-128

Piven J, Arndt S, Bailey J, Andreasen N (1996) Regional brains enlargement in autism: a magnetic resonance imaging study. J Am Acad Child Adolsec Psychiatry 35:530-536

Piven J (2001) The broad autism phenotype: a complementary strategy for molecular genetic studies of autism. Am J Med Genet 105:34 -35

Prater CD, Zylstra RG (2002) Autism: a medical primer. Am Fam Physician 66:1667-1674

Rapin I, Katzman R (1998) Neurobiology of autism. Ann Neurol 43:7-14

Risch N, Spiker D, Lotspeich L, Nouri N, Hinda D, Hallmayer J, Kalaydjieva L, McCague P, Dimiceli S, Pitts T, Nguyen L, Yang J, Harper C, Thorpe D, Vermeer S, Young H, Hebert J, Lin A, Ferguson J, Chiotti C, Wiese-Slater S, Rogers T, Salmon B, Nicholas P, Petersen PB, Pingree C, McMahon W, Wong DL, Cavalli-Sforza LL, Kraemer HC, Myers RM (1999) A genomic screen of autism: evidence for a multilocus etiology. Am J Hum Genet 65:493-507

Ritvo ER, Freeman BJ, Mason-Brothers A, Mo A, Ritvo AM (1985) Concordance for the spectrum of autism in 40 pairs of affected twins. Am J Psychiatry 142:74-77

Rodier PM, Hyman SL (1998) Early environmental factors in autism. Ment Retard Dev Disabil Res Rev 4:121-128

Rogers SJ (1998) Neuropsychology of autism in young children and its implications for early intervention. Ment Retard Dev Disabil Res Rev 4:104-112

Salmon B, Hallmayer J, Rogers T, Kalaydjieva L, Petersen PB, Nicholas P, Pingree C, McMahon W, Spiker D, Lotspeich L, Kraemer H, McCague P, Dimiceli S, Nouri N, Pitts T, Yang J, Hinds D, Myers RM, Risch N (1999) Absence of linkage and linkage disequilibrium to chromosome 15q11-q13 markers in 139 multiplex families with autism. Am J Med Genet 88: $551-556$

Shao Y, Wolpert CM, Raiford KL, Menold MM, Donnelly SL, Ravan SA, Bass MP, McClain C, von Wendt L, Vance JM, Abramson RK, Wright HH, Ashley-Koch AA, Gilbert JR, DeLong RG, Cuccaro ML, Pericak-Vance MA (2002a) A genomic screen and follow-up analysis for autism. Am J Med Genet 114:99-105

Shao Y, Raiford KL, Wolpert M, Cope HA, Ravan SA, Ashley-Koch AA, Abramson RK, Wright HH, DeLong RG, Gilbert JR, Cuccaro ML, Pericak-Vance MA (2002b) Phenotypic heterogeneity provides increased support for linkage on chromosome 2 in autistic disorder. Am $\mathbf{J}$ Hum Genet 70:1058-1061

Silverman JM, Smith CJ, Schmeidler J, Hollander E, Lawlor BA, Fitzgerald M, Buxbaum JD, Delaney K, Galvin P (2002) Symptom domains in autism and related conditions: evidence for familiality. Am J Med Genet 114:64-73

Smalley SL, Tanguay PE, Smith M, Gutierrez G (1992) Autism and tuberous sclerosis. J Autism Dev Disord 22:339-355

Smith M, Filipek PA, Wu C, Bocian M, Hakim S, Modahl C, Spence MA (2000) Analysis of a one mega base pair deletion in 15 q22-q23 in an autistic patient: identification of candidate genes for autism and of homologous DNA segments in 15q22q23 and 15q11-q13. Am J med Genet 96:765-770

Smith M, Escamilla JR, Filipek P, Bocian ME, Modahl C, Foldman P, Spence MA (2001) Molecular genetic delineation of 2q37.3 deletion in autism and osteodystrophy: report of a case and of new markers for deletion screening by PCR. Cytogenet Cell Genet 94:15-22
Spiker D, Lotspeich L, Kraemer HC, Hallmayer J, McMahon W, Petersen PB, Nicholas P, Pingree C, Wieseslater S, Chiotti C, Wong DL, Dimicelli S, Ritvo E, Cavallisforza LL, ciaranello RD (1994) Genetics of autism: Characteristics of affected and unaffected children from 37 multiplex families. Am J Med Genet 54:27-35

Steffenburg S, Gillberg C, Hellgren L, Andersson L, Gillberg IC, Kakobsson G, Bohman M (1989) A twin study of autism in Denmark, Finland, Iceland, Norway and Sweden. J Child Psychol Psychiatry 30:405-416

Steffenburg S, Gillberg CL, Steffenburg U, Kyllerman M (1996) Autism in Angelman syndrome: a population based study. Pediatr Neurol 14:131-136

Stubbs EG, Ash E, Williams CPS (1984) Autism and congenital cytomegalovirus. J Autism Dev Disord 14:183-189

Taylor B, Miller E, Lingam R, Andrews N, Simmons A, Stowe J (2002) Measles, mumps and rubella vaccination and bowel problem or developmental regression in children with autism: population based study. BMJ 324:393-396

Tentler D, Brandberg G, Betancur C, Gillberg C, Anneren G, Orsmark C, Green ED, Carlsson B, Dahl N (2001) A balanced reciprocal translocation $\mathrm{t}(5 ; 7)(\mathrm{q} 14 ; \mathrm{q} 32)$ associated with autistic disorder: molecular analysis of the chromosome7 breakpoint. Am J Med Genet 105:729-736

Thomas NS, Sharp AJ, Browne CE, Skuse D, Hardie C, Dennis NR (1999) Xp deletion associated with autism in three females. Hum Genet 104:43-48

Tomblin JB, Buckwalter PR (1998) Heritability of poor language achievement among twins. J Speech Lang Hear Res 41:188-199

Trottier G, Srivastava L, Walker CD (1999) Etiology of infantile autism: a review of recent advances in genetic and neurobiological research. J Psychiatr Neurosci 24:103-115

Vincent JB, Herbrick J-A, Gurling HMD, Bolton PF, Roberts W, Scherer SW (2000) Identification of a novel gene on chromosome $7 \mathrm{q} 31$ that is interrupted by a translocation breakpoint in an autistic individual. Am J Hum Genet 67:510-514

Vostanis P, Harrington R, Prendergast MFP (1994) Case reports of autism with interstitial deletion of chromosome 17 (p11.2p11.2) and monosomy of chromosome 5 (5pter-5p15.3). Psychiatr Genet 4:109-111

Wassink TH, Piven J, Vieland VJ, Huang J, Swiderski RE, Pietila J, Braun T, Beck G, Folstein SE, Haines JL, Sheffield VC (2001) Evidence supporting WNT2 as an autism susceptibility gene. Am J Med Genet 105:406-413

Wassink TH, Piven J, Vieland VJ, Pietila J, Goedken RJ, Folstein SE, Sheffield VC (2002) Evaluation of FOXP2 as an autism susceptibility gene. Am J Med Genet 114:566-569.

Weiss LA, Escayg A, Kearney JA, Trudeau M, MacDonald BT, Mori M, Reichert J, Buxbaum JD, Meisler MH (2003) Sodium channels SCN1A, SCN2A and SCN3A in familial autism. Mol Psychiatry 8:186-194

Wing 1, Gould J (1979) Severe impairments of social interaction and associated abnormality in children: epidemiology and classification. J Autism Dev Disord 9:11-29

Wing L (1997) The autistic spectrum. Lancet 350:1761-1766

Wolpert CM, Donnelly SL, Cuccaro ML, Hedges DJ, Poole CP, Wright HH, Gilbert JR, Pericak-Vance MA (2001) De novo partial duplication of chromosome $7 \mathrm{p}$ in a male with autistic disorder. Am J Med Genet 105:222-225

Yan WL, Guan X_Y, Green ED, Nicolson R, Yap TK, Zhang JH, Jacobsen LK, Krasnewich DM, Kumra S, Lenane MC, Gochman P, Damschroder-Williams PJ, Esterling LE, Long RT, Martin BM, Sidransky E, Rapoport JL, Ginns EI $(2000)$ Child-hood - onset schizophrenia/autistic disorder and $t(1 ; 7)$ reciprocal translocation: identification of a BAC contig spanning the translocation breakpoint at $7 \mathrm{q} 21$. Am J Med Genet 96:749-753

Yirmiya N, Pilowsky T, Nemanov L, Arbelle S, Feinsilver T, Fried I, Ebstein RP (2001) Evidence for an association with the serotonin transporter promoter region polymorphism and autism. Am J Med Genet 105:381-386 
Yu C-E, Dawson G, Munson J, D'Souza I, Osterling J, estes A, Leutenegger A-L, Flodman P, Smith M, Raskind WH, Spence MA, McMahon W, Wijsman EM, Schellenberg GD (2002) Presence of large deletions in kindreds with autism. Am J Hum Genet 71:100-115

Zilbovicius M, Garreau B, Samson Y, Ramy P, Barthelemy C, Syrota A, Lelord G (1995) Delayed maturation of the frontal cortex in childhood. Am J Psychiatry 152:248-252
Zilbovicius M, Boddaert N, Belin P, Poline JB, Remy P, Mangin JF, Thivard L, Barthelemy C, Samson Y (2000) Temporal lobe disfunction in childhood autism: A PET study. Am J Psychiatry 157:1988-1993

Zwaigenbaum L, Szatmari P, Jones MB, Bryson SE, Maclean JE, Mahoney WJ, Bartolucci G, Tuff LP (2002) Pregnancy and birth complications in autism and liability to the broader autism phenotype. J Am Acad Child Adolesc Psychiatry 41:572-579 